\title{
Population dynamics of the mussel Mytilus edulis: density changes and regulation of the population in the Exe estuary, Devon
}

\author{
S. McGrorty, R. T. Clarke, C. J. Reading, J. D. Goss-Custard \\ Institute of Terrestrial Ecology, Furzebrook Research Station, Wareham, Dorset BH20 5AS, United Kingdom
}

\begin{abstract}
Population dynamics of the intertidal mussel population in the River Exe estuary, Devon (UK) over 7 yr (1976 to 1983) are described. There was no significant trend in adult numbers, and annual variations were small ( 1.5 -fold, minimum to maximum). In contrast, the density of 'spat' mussels ( 0 -year) varied widely $(17 \times)$, suggesting that a strong damping process acted during the first year. Considering just first-year mortality, failure to settle on the beds $\left(\mathrm{k}_{3}\right)$ had the greatest influence on annual variations in total mortality $(\mathrm{K})$. But losses in the first winter after settlement $\left(\mathrm{k}_{5}\right)$ were strongly and positively density dependent. $k_{3}$ was inversely density dependent, but only in 6 out of 7 yr. Other first-year losses were independent of density. After the large first-winter mortality (mean $68 \%$ ), there were only small gains in summer and small losses in winter for the next 4 yr. Thereafter, increasingly large losses occurred (mean $39 \%$ ) each summer after spawning and each winter (mean $24 \%$ ), due mainly to bird predation. Some of the over-summer and over-winter changes in adult densities were density dependent, but their effect was small and only served as a 'fine tuning' mechanism keeping densities within very narrow limits. Though mortalities at various stages were correlated with the weather, the main feature of the population was its pronounced stability, due mainiy to the powerful regulation acting during the first year on the mussel beds.
\end{abstract}

\section{INTRODUCTION}

Identification and modelling of density-dependent regulatory processes in field and laboratory populations has been an important goal of ecologists for the last half-century. Depending upon the strength of the density dependence operating, even simple deterministic models show a range of population behaviour (Hassel et al. 1976, May 1986) from monotonic damping, through cyclical changes, to chaotic changes in density. Insects have frequently been studied (Crowley et al. 1987, Stiling 1988) but comparable studies have only rarely been made on marine benthic invertebrates (Hancock 1973, Dempster 1975).

Research on other groups has shown that long-term population studies are required to detect and measure density dependence (Hassell et al. 1989). The practical problems of sampling large, highly aggregated (sub) populations in difficult terrain may explain the paucity of long-term studies of benthic marine species (Hancock 1973, Vahl 1982, Bowman 1985, Barnett \& Watson 1986, Beukema \& Essink 1986). But, in addition, a particular problem of studying inshore marine benthic communities is that they tend to be dominated by a few species (Levin 1984, Paine 1984) with free-living, and often widely dispersing, planktonic larvae or progagules. In effect these are 'open' systems, in which individual species form metapopulations (Roughgarden \& Iwasa 1986), consisting of many local subpopulations, whose distribution, size and density may be 'limited' (Doherty 1983) or 'regulated' (Hughes 1990) by the supply of larvae from the plankton rather than by local fecundity. In contrast, the dispersal phase in insect metapopulations is usually the adult.

In these open populations of marine invertebrates there is, therefore, the particular problem of detecting local density dependence within subpopulations against a background of potentially massive domination by planktonic propagules that have almost certainly originated from other places. The relative importance of the density of settling propagules and of the post-settlement density-dependent and densityindependent processes in determining adult density has been the subject of recent debate (Holm 1990). Unfortunately, it is difficult to resolve, because marine ecologists have tended to concentrate on short-term 
and experimental investigations of factors which structure communities (Menge \& Farrell 1989) and operate within small 'patches' (Frid \& Townsend 1989). However, several density-related phenomena have been described in such studies, including density-dependent mortality (Hancock 1973, Beukema 1982), self-thinning (Hughes \& Griffiths 1988), density-limited growth (Morrisey 1987, Okamura 1986) and density-related emigration (Ambrose 1986). Therefore there was good reason to believe that a long-term population study would be able to measure the strength of any densitydependent regulatory processes acting on a local population.

The study was done on the common mussel Mytilus edulis L. in a sheltered Devon estuary where catastrophic mortalities due to storms and other disturbance agents, which dominate open rocky coast populations (Dare 1976, Sousa 1985), were unlikely to occur. That the study area was well sheltered was important: the mussel populations in large exposed, soft-sediment embayments resemble those on rocky shores, in that large densities of larvae (up to $10^{5} \mathrm{~m}^{-2}$ in Morecambe Bay, Dare 1976) settle onto 'clean' substrata, to form new, but short-lived, beds. But in small sheltered estuaries, mussel larvae generally settle only onto existing, long-lived, beds in hydrographically suitable areas (Verhagen 1982) and their densities are generally lower than in Morecambe Bay (pers. obs. and see this study). Since Dare et al. (1983) collected up to $10^{6}$ larvae $\mathrm{m}^{-1}$ of rope suspended in the water column in a sheltered estuary in Devon, it is likely that there are more larvae available to settle in such sites than actually do so. This suggested that these populations must be regulated by some factor operating on the mussel beds themselves and not by the availability of larvae.

This paper describes the dynamics of such a population in the Exe estuary in Devon (UK) as studied by kfactor analysis (Varley \& Gradwell 1960, Manly 1990). The entire intertidal population was studied because mussels are still mobile after settlement (Thieson 1968 , Sigurdsson 1976, Board 1983) which causes errors in mortality estimates in studies restricted to one place.

\section{SITE AND METHODS}

Study area. Mussel beds occur in the seaward half of the sheltered estuary of the River Exe, SW England (Fig. 1). Beds 3, 4, 30 and 31 have a shingle base and are probably natural, but many of the remaining beds in muddy areas were originally laid by man, though mussel fishing stopped in the 1950's.

Surveys. The intertidal mussels were sampled during spring tides in March and September each year from September 1976-1983. These dates coincided with (1)

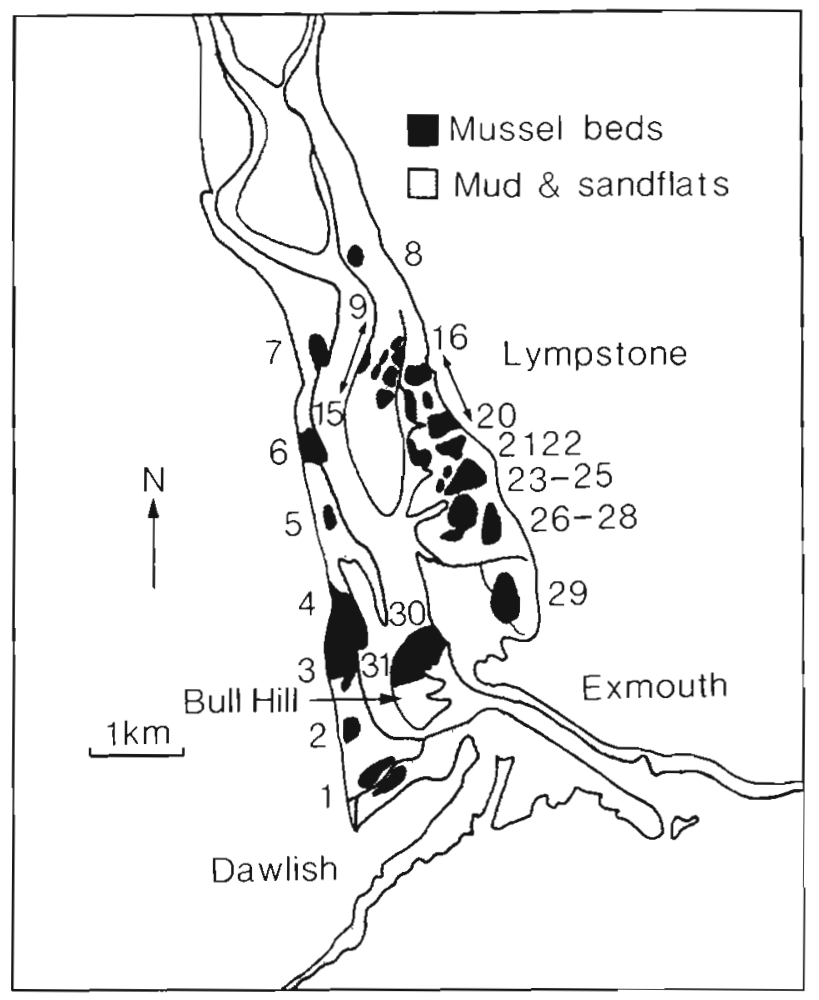

Fig. 1. River Exe estuary, showing location of Mytilus edulis beds (1 to 31) in September 1976. Some large areas of mussels were divided into 2 beds along natural boundaries, such as freshwater streams (Beds 3 and 4 ) or deep channels (Beds 30 and 31)

the early stages of gametogenesis in autumn (Seed 1976), (2) the spring peak of spat settlement (GossCustard et al. 1980) and (3) the arrival and departure of the main winter predator of adult mussels, the oystercatcher Haematopus ostralegus $\mathrm{L}$

Mussel beds were mapped to enable their area to be determined. A baseline was marked out alongside each bed. Regularly spaced transects, running at right angles to the baseline, were walked across the bed and the width measured between the 2 boundaries using a pacing stick. Between 9 and 20 transects were used on each bed, depending on its size.

Some beds were clearly divisible into separate subareas on the basis of the density and size of the mussels. Such sub-areas were regarded as strata for sampling, as were the whole of the more uniform beds. To give standard errors of 10 to $15 \%$ of the mean density, 600 samples were distributed between the 44 strata in proportion to their area and the standard deviation of their mussel density, using values obtained from the preceding survey. Within strata, sample sites were placed at random. To avoid bias, the box sampler 10.04 $\mathrm{m}^{2} \times 10 \mathrm{~cm}$ ) was placed squarely at the tip of the toe on completion of the last pace when the site was located. Any mussels present were placed in a labelled 
polythene bag and frozen until sorted on a $0.5 \mathrm{~mm}$ mesh sieve.

Two changes were made to this scheme. Of the 31 beds sampled in September 1976, 12 contained $82 \%$ of the mussel population. Storms had reduced the smaller beds to only $2 \%$ of the mussel population by March 1980 , so they were abandoned and sampling was restricted to the remaining 12 beds (21 strata). In response to the very large densities and variance of spat mussels on Beds 30 and 31, the sampling unit used there was reduced from March 1979 to $0.02 \mathrm{~m}^{2}$, and the number taken doubled. These 2 measures reduced the standard errors to 5 to $10 \%$ of the mean.

Aging mussel shells. Aging bivalves is difficult if size-frequency analysis (Bhattacharya 1967) is unsuccessful and rings caused by reduced growth in winter, spawning or disturbance can be confused. Both were true for our population though, with experience, rings did prove to be interpretable. Experience was obtained by following individual mussels, of a range of ages and lengths, placed individually in numbered plastic rings ( $4 \mathrm{~cm}$ diameter $\times 6 \mathrm{~cm}$ high) within cages $(30 \times 30 \times 6$ $\mathrm{cm}$ ) held horizontally between stakes $25 \mathrm{~cm}$ above 3 mussel beds to reduce the accumulation of mud. The cages were constructed of $1 \mathrm{~cm}$ galvanised wire weldmesh' and lined with $2 \mathrm{~mm}$ mesh nylon cloth on the bottom and $5 \mathrm{~mm}$ mesh on top of the rings. Mussels were measured periodically. This meant that the byssal threads had to be cut and this caused a disturbance ring to develop on the shell at a known length and date. By following shells of known history, we learned how to distinguish disturbance rings from annual rings.

As a check, lines were counted in the inner layer of sectioned and etched shells (Lutz 1976. Sheppard 1984), and in sectioned hinge ligaments. Both methods give accurate assessments of age, but were too timeconsuming for the routine examination of large samples. These tests showed that mussels were aged correctly by counting external annual shell rings in $95 \%$ of cases $(\mathrm{n}=40$ ). Only severely damaged or distorted shells could not be aged.

Aging shells from growth rings was still very time consuming, but their length could be measured rapidly. So, age distribution was calculated from length distribution, using an age-length relationship obtained from a sub-sample of mussels taken from each bed in each survey. There was little to be gained by aging more than $40 \%$ of the total sample (Clarke 1982); therefore, shells were grouped in $5 \mathrm{~mm}$ length catagories and $40 \%$ of each group selected at random. In practice, upper and lower limits of 75 and 20 shells were set.

Analysis of data. Mussels become adult in their second year, when they develop a gonad and first spawn. Mussels live for 10 or more years, and the study lasted only 7 yr. Therefore, it was not possible to follow a group of cohorts throughout their adult life, as is required by $\mathrm{k}$-factor analysis (Dempster 1975). This technique was therefore only used to compare mortalities between stages within the first year (Year 0 ). Tests for density dependence in adults were carried out on each age-class, from 1 to $9+y r$, using the different cohorts available (the 1975 to 1982 cohort at age 1 yr the 1974 to 1981 cohort at age $2 \mathrm{yr}, \ldots$.).

$\mathrm{K}$-factor analysis during the first year. The life cycle begins in autumn and early winter when primary oocytes develop and adult females achieve maximum weight. Each female releases eggs in batches throughout the following spring and summer, and by July most are spent. After $6 \mathrm{wk}$ or more in the plankton and primary settlement stages (Bayne 1964, 1976, McGrath et al. 1988), plantigrade larvae settle among adults on established beds or on suitable substrata to form new beds.

The first stage in the life cycle when density estimates could be made was of the plantigrades and recently-settled spat on the beds in March. Because the life cycle was considered to begin in the preceding autumn with egg production, 'Year 0 ' actually covered a period of $18 \mathrm{mo}$. Cohorts were referred to by their year of settlement. Thus, eggs within females in September 1976 gave rise to the 1977 cohort, sampled as plantigrades in March 1977. By March 1978, they had a single ring and were considered to be 1 yr old.

In $\mathrm{k}$-factor analysis, failure by females to produce the maximal potential number of eggs is regarded as mortality. In this study, it was defined as the maximal value measured for any estuary in SW England (Bayne et al. 1983) and was estimated using the expression: No. eggs $=4.94 \times 10^{6} \mathrm{AFDW}$, where AFDW = ash-free dry weight of adult female flesh in $g$ (B. L. Bayne pers. comm.). Total weight of female flesh was calculated from the length frequency distribution and an expression relating AFDW to length, assuming a 1:1 sex ratio. AFDWs were estimated for each bed in September 1976 by drying the flesh of randomly selected mussels at $80^{\circ} \mathrm{C}$, to constant weight. The expression was AFDW $(\mathrm{g})=0.0127 \pm 0.0031+2.748 \pm 0.065 \times$ length $(\mathrm{mm})$ Potential maximal egg production was calculated for each bed and summed to give estuary totals, for each survey.

Failure to produce the maximum potential eggs may result from a failure to grow to maximal size and therefore to maximal reproductive potential, or from a failure of animals of a given size to produce the maximal number of eggs. The latter could not be measured, therefore its importance, though likely to be small, could not be assessed. However, mussel length was measured so the first form of failure could be estimated. Maximal potential length at each age was defined 
either as the maximal length recorded on each bed, or as the maximal length recorded anywhere within the estuary. Table 1a summarises the density measurements made for each cohort to calculate potential losses of eggs and other mortalities itemised in Table $1 \mathrm{~b}$.

To identify the key factor, which explains the most variance between years in the total mortality during the egg and larval stages, each $\mathrm{k}$ was plotted against $\mathrm{K}$. The largest positive slope was defined as the key factor (Podolor \& Rogers 1975). Correlation coefficients were also calculated because a factor could have a strong slope, but poor correlation (Dempster 1983).

Tests for density-dependent mortality in which $\log$ survivors $\mathrm{S}$ is regressed against $\log$ initial density $\mathrm{N}$ assume no errors in the measurement of $\mathrm{N}$. In practice, both $\mathrm{N}$ and $\mathrm{S}$ were estimated and so prone to error, which will cause the slope of the relationship to be under-estimated (Slade 1977). No satisfactory method has yet been devised to overcome this problem, but those available were used here: (1) the conservative (Slade 1977) reversed axes test (Varley \& Gradwell 1968), (2) the less rigorous method of Bartlett (1949), as used by Hassell et al. (1987), (3) a major axis regression test (after Smith [1973], but with confidence limits for the slope given by Eq. (29.63) in Kendall \& Stuart [1979]). A further difficulty is that all these assume that mortality $\mathrm{k}$ is linearly related to $\log \mathrm{N}$. Smith (1973) suggested that $k$ was more likely to be lineary related to $\mathrm{N}$ than $\log \mathrm{N}$. This model was also tested using Methods (1) and (2) on k against N. Method (3) was inappropriate because the scales on the 2 axes were so different that the error variances could not be assumed to be the same, as the method assumes.

\section{RESULTS}

\section{General trends 1976 to 1983}

Neither the highly variable number of spat, nor the much less variable number of adult mussels, showed any trend over the study period (Fig. 2a). The densities, however, changed because the area occupied by mussels decreased by $24 \%$ (Fig. $2 \mathrm{~b}$,i). Thus densities of adults as a whole (Fig. $2 \mathrm{~b}$,ii), and some individual ageclasses (Fig. 3a) and size-classes (Fig. 3b) did increase over the study period (Table 2). In effect, the same number of mussels were compressed into a smaller area, mainly during three periods of contraction in the winters of 1976 to 1977,1979 to 1980 and the summer of 1981.

Table 1a. Description of the 6 stage density estimates made during Year $0 . E_{1}$ to $E_{3}$ are calculated estimates of potential egg production, $\mathrm{N}_{4}$ to $\mathrm{N}_{6}$ measured densities on the mussel beds

\begin{tabular}{|c|c|}
\hline $\begin{array}{l}\text { Stage } \\
\text { density } \\
\text { estimate }\end{array}$ & Description \\
\hline $\mathrm{E}_{1}$ & $\begin{array}{l}\text { Maximum potential egg production (MPEP) in September, based on, the eggs that would have been produced if } \\
\text { all the adult mussels, at each age, had achieved the maximum length ever recorded anywhere in the estuary for } \\
\text { that age }\end{array}$ \\
\hline $\mathrm{E}_{2}$ & $\begin{array}{l}\text { MPEP based on the eggs that would have been produced if all the adults, at each age, had achieved the } \\
\text { maximum length for that age recorded on the particular bed where they were growing }\end{array}$ \\
\hline $\mathrm{E}_{3}$ & Actual potential egg production calculated from actual lengths of mussels measured in the surveys \\
\hline $\mathrm{N}_{4}$ & Density of spat on beds in March \\
\hline $\mathrm{N}_{5}$ & Density of spat on beds in the following September \\
\hline $\mathrm{N}_{6}$ & Density of 1 -ring mussels in the following March \\
\hline
\end{tabular}

Table $1 b$. Description of the 5 stage mortalities estimated for Year 0

\begin{tabular}{|c|c|c|}
\hline Mortality & Derivation & Description \\
\hline $\mathrm{k}_{1}=$ & $\log E_{1}-\log E_{2}$ & Loss of potential eggs due to differences in growth of adult females on different beds within years \\
\hline $\mathrm{k}_{2}=$ & $\log E_{2}-\log E_{3}$ & Loss of potential eggs due to differences in growth of adult females from year to year, within beds \\
\hline $\mathrm{k}_{3}=$ & $\log E_{3}-\log N_{4}$ & Losses in plankton and primary settlement stages or failure to settle in the estuary \\
\hline $\mathrm{k}_{4}=$ & $\log N_{4}-\log N_{5}$ & First-summer losses on beds \\
\hline $\mathrm{k}_{5}=$ & $\log E_{5}-\log N_{6}$ & First-winter losses on beds \\
\hline \multicolumn{2}{|c|}{$\mathrm{K}=\mathrm{k}_{1}+\mathrm{k}_{2}+\mathrm{k}_{3}+\mathrm{k}_{4}+\mathrm{k}_{5}$} & Total mortality in Year 0 is the sum of individual stage mortalities \\
\hline
\end{tabular}



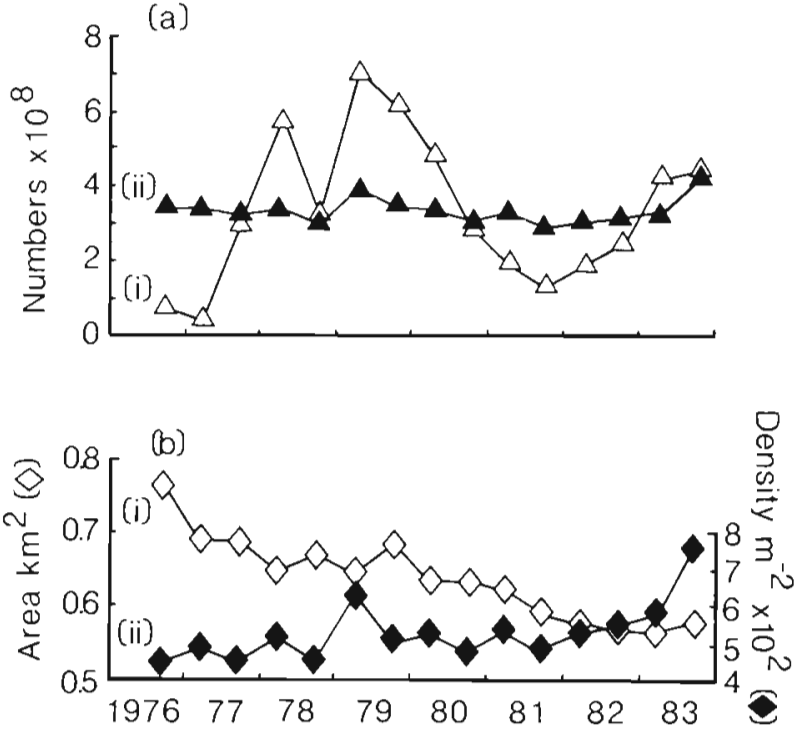

Fig. 2. General trends 1976 to 1983 ; (a, i) total number of Mytilus edulis spat $(0 \mathrm{yr})$; $(\mathrm{a}, \mathrm{ii})$ total number of adults; $(\mathrm{b}, \mathrm{i})$ bed area; (b, ii) adult density

\section{Changes in density between age and size-classes}

There was a large reduction in density during the first year on the beds (Fig. 4a). There was then little change until the fifth year, when density once again declined rapidly. Few individuals older than 10 yr were

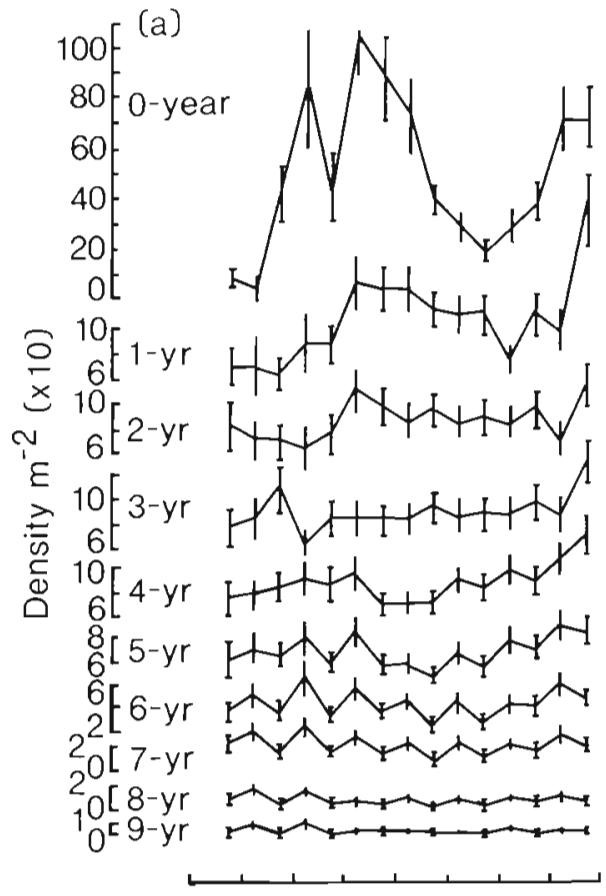

197677787980818283 found. The same trends occurred when size, rather than age-classes, were plotted (Fig. 4b). The greatest decrease occurred between the smallest size-classes; i.e., at or soon after settlement. In both cases, the coefficient of variation between years was greatest during the early and late stages of life when the average rate of change in densities was also fastest (Fig. $4 \mathrm{a}$, b).

\section{Gains and losses of mussels in relation to age}

Following the highly variable rates of recruitment to the mussel beds and subsequent losses in the first summer (March to September), there was a mean loss of $68.2 \pm 6.8 \%$ during the first winter (September to March) (Fig. 5). For the next $4 \mathrm{yr}$, there were only small gains in summer and small losses in winter. From the 6 th year onwards, there were increasingly large losses each year both in summer (mean $38.6 \pm 3.7 \%$ ) and winter (mean $24.1 \pm 2.9 \%$ ). But not all of these changes in density were significantly different from zero. Because the data were skewed, $t$-tests were carried out, at the 5 and $1 \%$ probability levels $\left({ }^{\circ}, \cdots\right.$, Fig. 5), using net proportional change on a logarithmic scale to approximate normality. These tests showed that there was a significant increase in density, from immigration, only in the 4 th summer; but significant losses occurred in the 6 th to the 10 th summers and in the 1 st and 6 th to the 8 th winters.

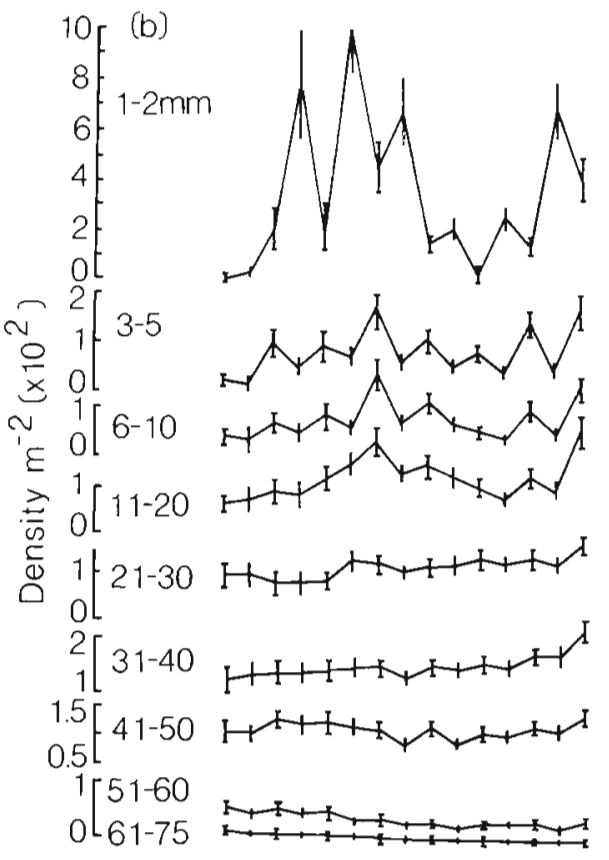

197677787980818283

Fig. 3. Mytilus edulis. Changes in density with time, by (a) age and (b) length. Vertical bars are $95 \%$ confidence intervals. $\mathrm{I}=$ September and $\mid=$ March values 
Table 2. Mytilus edulis. Trends in density against time by age and length. ns: not significant

\begin{tabular}{|c|c|c|c|c|c|c|c|}
\hline $\begin{array}{l}\text { Age } \\
\text { class } \\
\text { (Year) }\end{array}$ & $\begin{array}{c}\text { Slope of } \\
\text { regression } \\
b\end{array}$ & $\begin{array}{c}\text { Variance } \\
\text { explained } \\
r^{2} \%\end{array}$ & $\begin{array}{c}\text { Level of } \\
\text { significance } \\
p\end{array}$ & $\begin{array}{c}\text { Length } \\
\text { category } \\
\text { (mm) }\end{array}$ & $\begin{array}{c}\text { Slope of } \\
\text { regression } \\
b\end{array}$ & $\begin{array}{c}\text { Variance } \\
\text { explained } \\
\mathrm{r}^{2 \%}\end{array}$ & $\begin{array}{c}\text { Level of } \\
\text { significance } \\
p\end{array}$ \\
\hline 0 & 13.43 & 3.8 & ns & $<2$ & 7.65 & 1.2 & ns \\
\hline 1 & 4.56 & 35.5 & $p<0.05$ & $3-5$ & 4.65 & 19.2 & ns \\
\hline 2 & 1.65 & 24.8 & ns & $6-10$ & 2.61 & 9.8 & ns \\
\hline 3 & 2.29 & 35.4 & $\mathrm{p}<0.05$ & $11-20$ & 3.97 & 19.0 & ns \\
\hline 4 & 2.13 & 38.6 & $\mathrm{p}<0.05$ & $21-30$ & 3.79 & 64.2 & $\mathrm{p}<0.01$ \\
\hline 5 & 0.90 & 10.9 & ns & $31-40$ & 4.33 & 63.2 & $p<0.01$ \\
\hline 6 & 0.14 & 0.3 & ns & $41-50$ & 0.28 & 0.7 & ns \\
\hline 7 & -0.15 & 0.8 & ns & $51-60$ & 1.65 & 0.1 & ns \\
\hline 8 & -0.17 & 3.9 & ns & $61-70+$ & -0.94 & 79.5 & $p<0.01$ \\
\hline $9+$ & -0.12 & 4.5 & ns & & & & \\
\hline $1-9+$ & 10.68 & 39.5 & $p<0.05$ & & & & \\
\hline
\end{tabular}
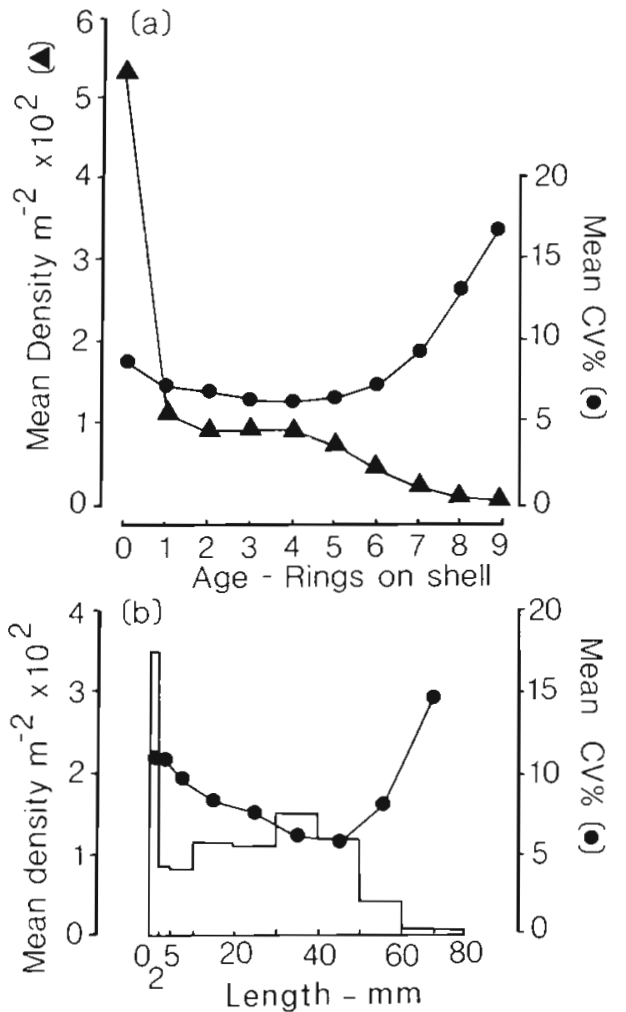

Fig. 4. Mytilus edulis. Changes in mean density (1976 to 1983) and coefficients of variation (CV\%) by (a) age and (b) length. $\mathrm{CV} \%$ : error of estimation of mean densities and nature of distribution; high values indicate aggregation, low values a more even distribution

Small clumps of mussels were seen to move between beds within the Exe. Futher substantial quantities of adults were storm-driven into the estuary, and onto Bull Hill in particular. Such immigrations were seen in the winter of $1977 / 78$ and in the autumn of 1983 . The largest of these in 1983 resulted in significant increases ( $\mathrm{p}<0.05$, t-tests) through immigration in the density of

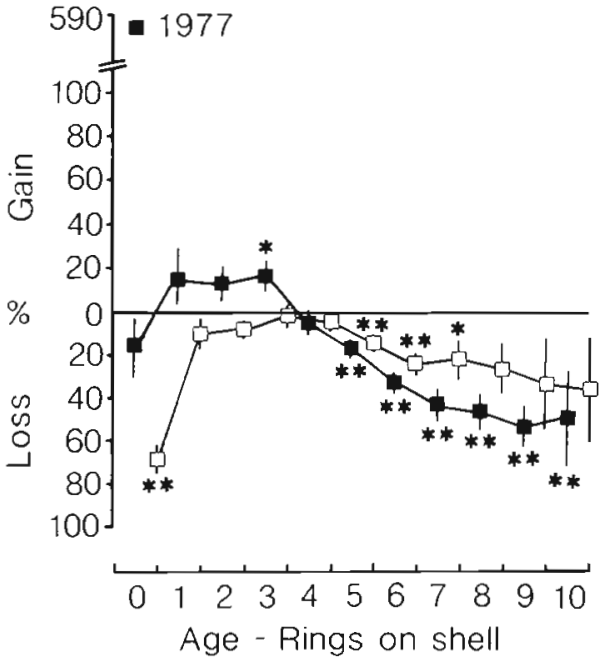

Fig. 5. Mytilus edulis. Arithmetic mean gains and losses (\% change) in summer (-) and winter (ㅁ) in relation to age. Vertical bars: 2 standard errors: $\cdots$ statistically significant changes in density at $p<0.05$ and $<0.01$ respectively, using net proportional change analysed on a log scale to approximate to normality. The null hypothesis of no net change was rejected when $\bar{x} \pm t \times$ standard error did not include zero

1, 2 and 3 yr-olds of 92,54 and $46 \%$ respectively. Though not observed directly, immigration was also indicated by a significant increase ( $\mathrm{p}<0.05$, $\mathrm{t}$-test) in the density of young adults in the summer of 1982 .

\section{$\mathrm{K}$-factor analysis of young stages}

\section{Key factor}

Failure to settle in the estuary $\left(\mathrm{k}_{3}\right)$ was the key factor. It had the largest regression coefficient (Table 3) and thus the greatest influence on annual variations in the total generation mortality $(\mathrm{K})$ within Year 0 . It also had 
Table 3. Mytilus edulis. Key factor in Year 0: ordinary regression coefficients (b) and correlation coefficients $(r)$ for individual mortalities $(k)$ against total generation mortality $(K) . k_{1}$ and $k_{2}$ are losses of potential eggs, $k_{3}$ failure to settle on the beds, $\mathrm{k}_{4}$ losses during the first summer and $\mathrm{k}_{5}$ losses during the first winter

\begin{tabular}{|crrr|}
\hline $\mathrm{x}, \mathrm{y}$ & $\mathrm{b}$ & $\mathrm{r}$ & Mean $\mathrm{k}_{\mathrm{1}}$ \\
\hline $\mathrm{K}, \mathrm{k}_{1}$ & 0.050 & 0.353 & 0.106 \\
$\mathrm{~K}, \mathrm{k}_{2}$ & 0.124 & 0.365 & 0.316 \\
$\mathrm{~K}, \mathrm{k}_{3}$ & 3.839 & 0.723 & 5.814 \\
$\mathrm{~K}, \mathrm{k}_{4}$ & -2.401 & -0.500 & -0.037 \\
$\mathrm{~K}, \mathrm{k}_{5}$ & -0.612 & -0.419 & 0.618 \\
\hline
\end{tabular}

Table 4. Mytilus edulis. Key factor in Year 0: ordinary regression coefficients (b) and correlation coefficients ( $\mathrm{r}$ ) for individual mortalities $(\mathrm{k})$ against total generation mortality $(\mathrm{K})$, omitting $\mathrm{k}_{3}$

\begin{tabular}{|c|c|c|c|c|c|c|}
\hline & \multicolumn{3}{|c|}{ All years } & \multicolumn{3}{|c|}{ Without 1977 cohort } \\
\hline & & & Mean & & & Mean \\
\hline & $b$ & $\mathrm{r}$ & $\mathrm{k}_{\mathrm{i}}$ & $\mathrm{b}$ & r & $\mathrm{k}_{\mathrm{i}}$ \\
\hline $\mathrm{K}_{1} \mathrm{k}_{1}$ & -0.0014 & -0.0463 & 0.106 & -0.0745 & -0.759 & 0.107 \\
\hline$K_{1} k_{2}$ & 0.0288 & 0.3920 & 0.316 & -0.1160 & -0.589 & 0.323 \\
\hline $\mathrm{K}, \mathrm{k}_{4}$ & 0.9910 & 0.9590 & -0.037 & 0.6610 & 0.595 & 0.123 \\
\hline $\mathrm{K}, \mathrm{k}_{5}$ & -0.0188 & -0.0598 & 0.618 & 0.6690 & 0.601 & 0.607 \\
\hline
\end{tabular}

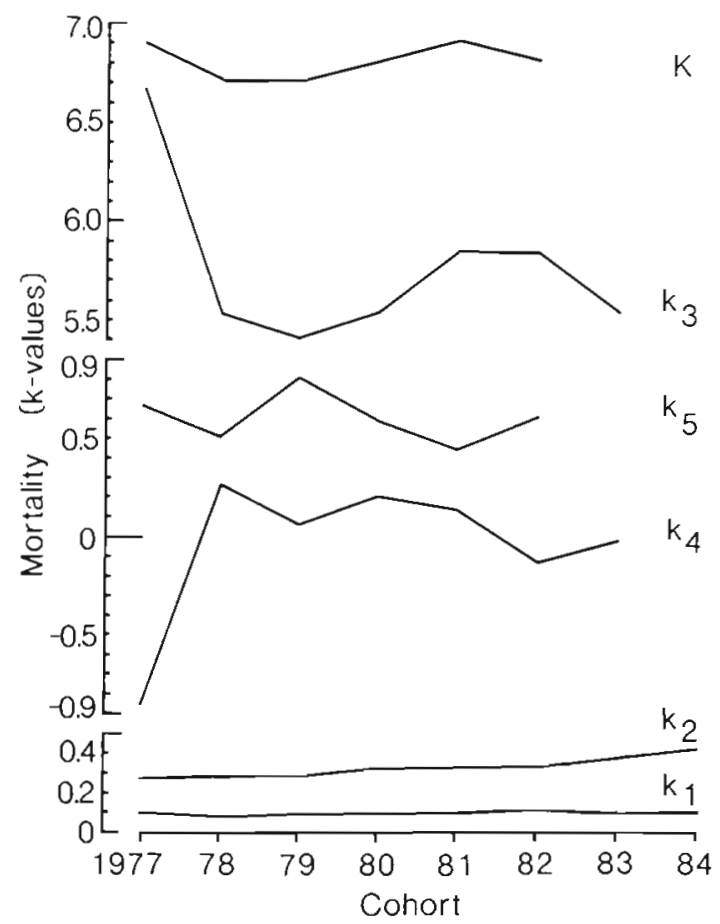

Fig. 6. Mytilus edulis. Comparison of total mortality (K) of 1977 to 1982 cohorts of mussels with individual mortalities $\left(\mathrm{k}_{1}\right.$ to $\left.\mathrm{k}_{5}\right)$ in Year 0 , from potential eggs to 1 -yr-old adults (Table $1 \mathrm{~b}$ ). $\mathrm{k}_{1}$ and $\mathrm{k}_{2}=$ losses of potential eggs; $\mathrm{k}_{3}=$ failure of larvae to settle in the estuary; $k_{4}$ and $k_{5}=$ first summer and first winter losses respectively, on the beds. $\mathrm{K}=\mathrm{k}_{1}+\mathrm{k}_{2}+\mathrm{k}_{3}+\mathrm{k}_{4}+\mathrm{k}_{5}$ by far the largest mean value and, therefore, the greatest influence on the level of the total mortality (Fig. 6). On average, the density of spat on the beds in March. represented only $0.0002 \%$ of the actual potential egg production $\left(E_{3}\right)$ present in the population the preceeding September.

Because $k_{3}$ was so dominant, the data were reanalysed with this factor excluded to assess the relative importance of the remaining individual mortalities. The first-summer mortality $\left(\mathrm{k}_{4}\right)$ then had the largest regression coefficient (Table 4) and was highly correlated with the total mortality $\left(\mathrm{K}-\mathrm{k}_{3}\right)$. This was entirely due to the 1977 cohort which, having failed to settle in spring, was recruited gradually throughout the summer and so had a large negative $\mathrm{k}$-value. Without the 1977 cohort, the coefficients (Table 4) for $\mathrm{k}_{4}$ and $\mathrm{k}_{5}$ were very similar, so their effect on variations in total mortality was also similar. But $\mathrm{k}_{5}$ had a higher mean value and was more important in determining the level of the total generation mortality. The first-winter mortality $\left(\mathrm{k}_{5}\right)$ was therefore the most important mortality after $\mathrm{k}_{3}$.

\section{Density dependence}

Only first-winter loss $\left(\mathrm{k}_{5}\right)$ was closely and positively density dependent (Fig. 7b), but even this was not supported by all the tests of significance (Table 5). It reached significance with the major axis regression test and also with the reversed axes test when $\mathrm{k}_{5}$ was regressed against $N_{5}$ rather than $\log N_{5}$. There is therefore some evidence that the greater the density of 0 year mussels in September, the greater was the mortality during the following (first) winter.

Most of the remaining mortalities were independent of density. $\mathrm{k}_{3}$ was significantly inversely density dependent, but only when the exceptional cohort of 1977 was excluded: with that year included, the relationship became not only non-significant but also reversed its sign (Table 5). Nor were any of the mortalities related significantly to the densities of older mussels whether these were defined as young ( 1 to $4 \mathrm{yr}$ old $)$, old $(5+y \mathrm{y}$ old $)$ or all adults $\left(\mathrm{r}^{2}=0.4-47 \%, \mathrm{p}>\right.$ $0.05) . k_{2}$ was excluded from this analysis as the density of adults had a major influence on the calculation of the densities of eggs. It is therefore concluded that the only density dependence in Year 0 occurred over the first winter after the spat had settled on the beds, and depended on the density of spat in the preceeding autumn.

\section{Effect of weather}

Despite the highest potential egg production in September 1976, settlement on the beds in spring 1977 was 


\section{Patterns in adult mortality}

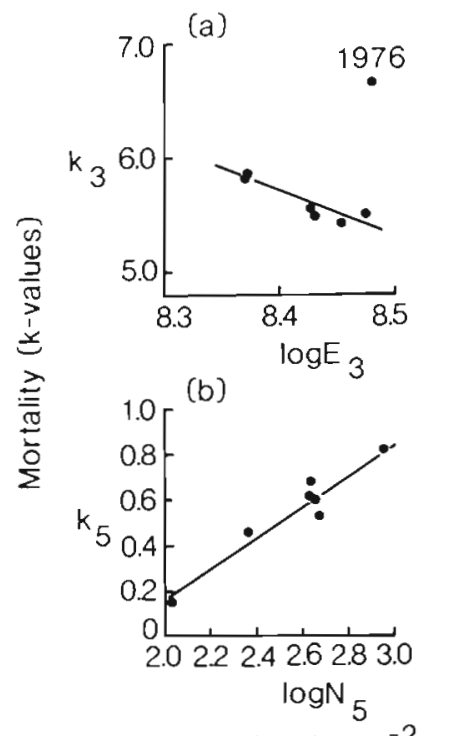

Initial density $\mathrm{m}^{-2}$
Fig. 7. Mytilus edulis. Regression analyses. (a) Inversely density-dependent failure to settle on the beds in March, $\mathrm{k}_{3}$, against density of potential eggs $\left(\log E_{3}\right)$ in the preceeding September: without 1976 (the 1977 cohort), $\mathrm{k}_{3}=38.69-$ $3.93 \log E_{3}, r^{2}=83 \%$; with the 1977 cohort, $\mathrm{r}^{2}=2 \%$. (b) Density dependent first winter losses on the beds, $\mathrm{k}_{5}$, against the density of mussel spat $\left(\log N_{5}\right)$ in September, $\mathrm{k}_{5}=0.69 \log \mathrm{N}_{5}$ $1.20, \mathrm{r}^{2}=93 \%$

the lowest recorded. This followed an exceptionally hot summer and exceptionally wet winter and spring. Therefore, $\mathrm{k}$-values were regressed against air temperature, rainfall and the number of days with gales during the period over which the mortality operated (Table 6).

Egg losses due to annual variation in female growth $\left(\mathrm{k}_{2}\right)$ correlated with the incidence of gales in summer. Failure to settle on the beds $\left(k_{3}\right)$ correlated with rainfall. Mortality during the first winter $\left(\mathrm{k}_{5}\right)$ increased in warmer than average winters and decreased with increased rainfall in winter; though the significance of the latter depended entirely on the twice average rainfall in $1976 / 77$.

\section{Density dependence}

Evidence of density-dependent mortality of adults was found only for their 10 th summer and 2 nd winter, and of inverse density dependence only in the 5th winter. However, the proportion of the variation in the mortality of an age-class explained by these relationships was small (Table 7 ) and the weak, inverse density dependence in the 5 th winter probably arose by

Table 6. Mytilus edulis. Correlation coefficients ( $\mathrm{r}$ ) between mortalities ( $\mathrm{k}$-values) and weather variables measured over the 6 mo prior to or during which the mortality was acting. Only those adult stages are included for which significant correlations were found; ${ }^{*}$ and ${ }^{\prime}$ indicate significant correlations at the 5 and $1 \%$ probability levels respectively. Adult stages indicate the age of the mussels e.g. 2nd summer refers to 1 -yr-olds in their second summer. $\mathrm{n}=7,1976$ to 1983

\begin{tabular}{|c|c|c|c|}
\hline Mortality & $\begin{array}{c}\text { Temperature, } \\
\text { deviation } \\
\text { from } 30 \mathrm{yr} \\
\text { average }\left({ }^{\circ} \mathrm{C}\right)\end{array}$ & $\begin{array}{l}\text { Rain, } \\
\% \text { of } \\
30 \text { yт } \\
\text { average }\end{array}$ & $\begin{array}{l}\text { Days } \\
\text { with } \\
\text { gales }\end{array}$ \\
\hline \multicolumn{4}{|l|}{ First year } \\
\hline $\mathrm{k}_{1}$ & 0.163 & 0.307 & 0.617 \\
\hline $\mathrm{k}_{2}$ & 0.316 & 0.564 & $0.830^{\circ}$ \\
\hline $\mathrm{k}_{3}$ & -0.546 & $0.831^{\circ}$ & -0.579 \\
\hline $\mathrm{k}_{4}$ & -0.282 & -0.069 & 0.210 \\
\hline $\mathrm{k}_{5}$ & $0.812^{\circ}$ & $-0.762^{\circ}$ & 0.420 \\
\hline \multicolumn{4}{|l|}{ Adults } \\
\hline $\mathrm{k}$ 2nd summer & $-0.766^{\circ}$ & -0.127 & $-0.802^{\circ}$ \\
\hline k 2nd winter & $0.795^{\circ}$ & -0.325 & -0.053 \\
\hline k 6th summer & $-0.865^{\circ}$ & -0.223 & -0.343 \\
\hline k 7 th summer & $-0.787^{\circ}$ & -0.562 & -0.631 \\
\hline k 8th summer & -0.718 & -0.477 & $-0.898^{\cdots}$ \\
\hline k 9th summer & -0.029 & -0.115 & $-0.845^{\circ}$ \\
\hline $\mathrm{k}$ 10th summer & -0.245 & -0.465 & $-0.759^{\circ}$ \\
\hline
\end{tabular}

Table 5. Mytilus edulis. Density-dependent mortality in Year 0: ordinary regression coefficients (b) and the proportion of variance explained $\left(\mathrm{r}^{2}\right)$ for individual mortalities $(\mathrm{k})$ against $\log$ densities before the mortality operated. $E_{1}, E_{2}$ and $E_{3}$ are estimates of potential egg production per $\mathrm{m}^{2}$ of mussel bed. $\mathrm{N}_{4}$ and $\mathrm{N}_{5}$ are densities of spat in March and the following September respectively. Results of 3 tests for density dependence are shown: $\mathrm{p}<0.05$ indicates that the test supports the hypothesis of density-dependent mortality at the $5 \%$ level of probability. ns: no support; na: test not appropriate. 1977 cohort omitted

\begin{tabular}{|c|c|c|c|c|c|}
\hline$y, x$ & $b$ & $r^{2} \%$ & $\begin{array}{c}\text { Reversed } \\
\text { axes }\end{array}$ & Bartlett's & $\begin{array}{l}\text { Major } \\
\text { axes }\end{array}$ \\
\hline $\mathrm{k}_{1}, \log \mathrm{E}_{1}$ & $1.69 .10^{-3}$ & 0.01 & ns & ns & ns \\
\hline $\mathrm{k}_{2}, \log \mathrm{E}_{2}$ & 0.557 & 51.00 & ns & ns & ns \\
\hline $\begin{array}{l}k_{3}, \log E_{3} \\
k_{3}, \log E_{3} .\end{array}$ & $\begin{array}{r}1.354 \\
-3.926\end{array}$ & $\begin{array}{r}2.00 \\
82.60\end{array}$ & $\begin{array}{c}\text { ns } \\
\mathrm{p}<0.05\end{array}$ & $\begin{array}{c}\text { ns } \\
\mathrm{p}<0.05\end{array}$ & $\begin{array}{c}\text { ns } \\
p<0.05\end{array}$ \\
\hline $\begin{array}{l}k_{4}, \log N_{4} \\
k_{4}, \log N_{4} .\end{array}$ & $\begin{array}{l}0.792 \\
0.275\end{array}$ & $\begin{array}{l}79.50 \\
18.00\end{array}$ & $\begin{array}{l}\mathrm{ns} \\
\mathrm{ns}\end{array}$ & $\begin{array}{l}\text { ns } \\
\text { ns }\end{array}$ & $\begin{array}{l}\text { ns } \\
\text { ns }\end{array}$ \\
\hline $\begin{array}{l}\mathrm{k}_{5}, \log N_{5} \\
\mathrm{k}_{5}, \mathrm{~N}_{5}\end{array}$ & $\begin{array}{l}0.685 \\
7.43 \cdot 10^{-4}\end{array}$ & $\begin{array}{l}92.90 \\
78.80\end{array}$ & $\begin{array}{c}\mathrm{ns} \\
\mathrm{p}<0.05\end{array}$ & $\begin{array}{l}\mathrm{ns} \\
\mathrm{ns}\end{array}$ & $\begin{array}{c}\mathrm{p}<0.05 \\
\text { na }\end{array}$ \\
\hline
\end{tabular}


Table 7. Mytilus edulis. Adult density-dependent mortality: ordinary regression coefficients (b) for individual stage mortalities (kvalues) against the density ( $N$ ) before the mortality operated. Only those stages for which the hypothesis of density-dependent mortality was supported at the $5 \%$ probability level $(\mathrm{p}<0.05)$ by one or more tests are presented. Major axis test did not support the hypothesis at any stage. ns: not significant

\begin{tabular}{|c|c|c|c|c|c|}
\hline \multirow[b]{2}{*}{ Period of mortality } & \multirow[b]{2}{*}{$y, x$} & \multirow[b]{2}{*}{$\mathrm{b}$} & \multirow[b]{2}{*}{$r^{2 \%} \%$} & \multicolumn{2}{|c|}{ Tests for density dependence } \\
\hline & & & & Reversed axes & Bartlett's \\
\hline 10th summer & $\begin{array}{l}k, \log N \\
k, N\end{array}$ & $\begin{array}{l}1.098 \\
0.085\end{array}$ & $\begin{array}{l}50.9 \\
57.8\end{array}$ & $\begin{array}{c}\text { ns } \\
p<0.05\end{array}$ & $\begin{array}{l}p<0.05 \\
p<0.05\end{array}$ \\
\hline 2nd winter & $\begin{array}{l}\mathrm{k}, \log \mathrm{N} \\
\mathrm{k}, \mathrm{N}\end{array}$ & $\begin{array}{l}0.741 \\
0.004\end{array}$ & $\begin{array}{l}63.8 \\
68.2\end{array}$ & $\begin{array}{c}\text { ns } \\
p<0.05\end{array}$ & $\begin{array}{l}\text { ns } \\
\text { ns }\end{array}$ \\
\hline 5th winter & $k, \log N$ & -0.414 & 49.6 & ns & $\mathrm{p}<0.05$ \\
\hline
\end{tabular}

chance, as the range of values was very narrow, and formed only a tight cluster of points when plotted.

In the case of the 10th summer mortality a greater proportion of the variance was explained when mortality was regressed against the density of all adults and not just that of the 10-yr-olds themselves (Table 8 ). Second-winter mortality was also related to the density of all adults, though a greater proportion of the variance was explained by plotting $\mathrm{k}$ against the density of only the young adults ( 1 to $4 \mathrm{yr}$ ). There was no evidence that the mortality of any other adult age-class was related to the density of other adults, except when the 1983 data were omitted. Then mortality during the 4 th, 5 th and 6th summers was also significantly related to the total density of young or all adults (Table 8). In each case, the $1983 \mathrm{k}$-value was large and negative, the result of storm-driven immigration into the estuary in the week prior to sampling (own obs.).

\section{Effect of weather}

Losses in the second summer were greatest in cooler than average years and lowest in years with the most gales (Table 6). Losses in the second winter were great- est in warmer than average years. Thereafter losses in winter were not related to any of the measures of weather used. Losses in summer increased in the 6th and 7 th years in cooler than average years and decreased in the 8 th, 9 th and 10 th year as the incidence of gales increased.

\section{Do good spat-years lead to more adults?}

Despite the constancy of adult numbers (Fig, 2a, ii), their density did vary a little in relation to how much spat had settled in previous years. For example, the increase in the total number of adult mussels in March 1979 (Fig. 2a, ii) was due to an increase in the 1-yr group which followed the 1978 peak in spat (Figs. $2 a$, i and 3 a). On the other hand, the 1979 peak in spat did not follow through to an increase in the number of adults in later years.

To test the degree to which variations in adult numbers could be traced back to variations in spat settlement, the densities of cohorts as spat were plotted against their subsequent densities as adults. With only 7 years of data available, this could only be done for cohorts up to the age of 4 yr old (Fig. 8). All slopes were

Table 8. Mytilus edulis. Density-related adult mortality: ordinary regression coefficients (b) for individual stage mortalities (kvalues) against the density (logN) of 'young', 1 to $4 / 5$-yr-old, or all, 1 to $9 / 10$-yr-old adults as a group before the mortality operated. Only those stages for which the hypothesis of density-dependent mortality was supported at the $5 \%$ probability level (p<0.05) by one or more tests are presented. Major axis test did not support the hypothesis at any stage. ns: not significant. ' 1983 data omitted

\begin{tabular}{|c|c|c|c|c|c|}
\hline \multirow[b]{2}{*}{ Period of mortality } & \multirow[b]{2}{*}{$y, x$} & \multirow[b]{2}{*}{$\mathrm{b}$} & \multirow[b]{2}{*}{$r^{2} \%$} & \multicolumn{2}{|c|}{ Tests for density dependence } \\
\hline & & & & Reversed axes & Bartlett's \\
\hline 10th summer & $k, \log N_{1-10 \mathrm{yr}}$ & -7.280 & 71.9 & $p<0.05$ & ns \\
\hline 2nd winter & $\begin{array}{l}k, \log N_{1-9 y r} \\
k, \log N_{1-4 y r}\end{array}$ & $\begin{array}{l}2.858 \\
2.178\end{array}$ & $\begin{array}{l}69.8 \\
75.2\end{array}$ & $\begin{array}{l}p<0.05 \\
p<0.05\end{array}$ & $\begin{array}{c}\mathrm{p}<0.05 \\
\mathrm{~ns}\end{array}$ \\
\hline 4 th summer ${ }^{\circ}$ & $\mathrm{k}, \log \mathrm{N}_{1-5 \mathrm{yr}}$ & 1.068 & 90.4 & $p<0.05$ & $p<0.05$ \\
\hline 5th summer & $\begin{array}{l}\mathrm{k}, \log N_{1-5 y \mathrm{r}} \\
\mathrm{k}, \log \mathrm{N}_{1-10 \mathrm{yx}}\end{array}$ & $\begin{array}{l}1.000 \\
1.523\end{array}$ & $\begin{array}{l}73.5 \\
87.2\end{array}$ & $\begin{array}{l}p<0.05 \\
p<0.05\end{array}$ & $\begin{array}{c}\mathrm{ns} \\
\mathrm{p}<0.05\end{array}$ \\
\hline 6 th summer" & $\mathrm{k}, \log N_{1-10 \mathrm{yr}}$ & 1.303 & 69.1 & $p<0.05$ & $\mathrm{~ns}$ \\
\hline
\end{tabular}




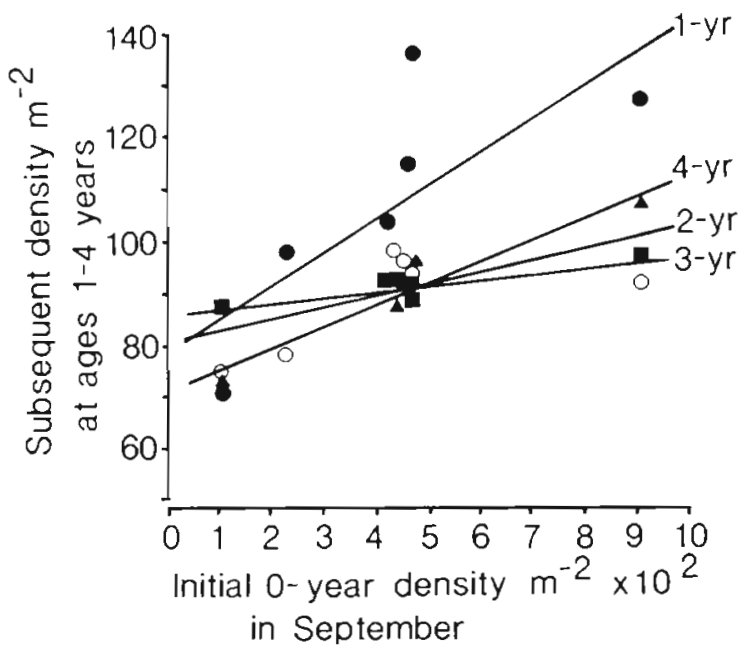

Fig. 8. Mytilus edulis. Regression analyses of the density of spat ( 0 -yr: $x)$ against their subsequent densities at ages $1,2,3$ and 4 yr $(y)$ : at 1 yr $(\bullet), n=7, y=0.066 x+77.99, r^{2}=53 \%$, ns and $y=61.88 \log x+52.20, r^{2}=66 \%, p<0.05$; at $2 y r$ (D). $\mathrm{n}=6, \mathrm{y}=0.024 \mathrm{x}+80.11, \mathrm{r}^{2}=27 \%$, ns and $\mathrm{y}=27.77 \log \mathrm{x}+$ $19.63, \mathrm{r}^{2}=50 \%$, ns; at $3 \mathrm{yr}(0), \mathrm{n}=5, \mathrm{y}=0.012 \mathrm{x}+85.54, \mathrm{r}^{2}=$ $94 \%, \mathrm{p}<0.01$; at 4 yr $(\mathbf{4}), \mathrm{n}=4, \mathrm{y}=0.043 \mathrm{x}+70.28, \mathrm{r}^{2}=96 \%$, $p<0.05$. ns: relationship is not significant at the $5 \%$ probability level

positive. Thus, in general, cohorts with more spat produced more young adults of age 1 to $4 \mathrm{yr}$. A greater proportion of the variance for cohorts at age 1 and $2 \mathrm{yr}$ was in fact explained by using log spat densities, suggesting that density levelled off above a certain point. Further analysis indicated that a ceiling density of ca $130 \mathrm{~m}^{-2}$ and $95 \mathrm{~m}^{-2}$ existed for 1 -yr-old and 2 -yr-old individuals, respectively.

\section{DISCUSSION}

Though a numerical model of the population dynamics of the intertidal mussels of the Exe is still in preparation, on overall synthesis can be attempted. Many mussel spat in large intertidal areas, like Morecambe Bay (Dare 1976) and the Wadden Sea (Beukema 1982), settle onto stony 'skears' or sand to form new beds. In these areas, great variability in recruitment is carried through almost completely to the adult biomass. In small estuaries spat rarely settle elsewhere than on established beds. In the Exe the highly variable recruitment was quickly and strongly damped. In fact, the 17 -fold annual variation in spat density in spring was reduced to a 1.5 -fold variation in the densities of adults more than 1 yr old. The cause of this damping was the powerful first-winter, density-dependent mortality of the 0 -yr class on the mussel beds.

This mortality was probably caused mainly by juvenile crabs Carcinus maenas. In a trial field experi- ment over a single high-water period, 96 to $100 \%$ in $=$ 6) of 2 to $16 \mathrm{~mm}$ spat were lost when no adult mussels were present, whereas only 30 to $53 \%$ disappeared when older mussels were present $(p<0.001)$. The remaining broken shells showed that they had been eaten by crabs (Dare et al. 1983). Indeed crabs are the main predator of commercial 'seed' mussels (Dare \& Edwards 1976) and 'crab-proof' fences improved yields 4 to 5 fold (Davies et al. 1980). Juvenile crabs are voracious predators of benthic invertebrates (Jensen \& Jensen 1985, Reise 1985), including young mussels (Reynolds 1969, Harger 1972, Walne \& Dean 1972), and experiments have shown that they can greatly decrease prey populations (Gee et al. 1985).

Of the potential predators, only crabs were abundant on the Exe mussel beds. Other potential predators, such as dogwelks (Kitching et al. 1959, Hughes \& Dunkin 1984) and starfish (Dare 1982, O'Neill et al. 1983), were rarely seen, and shorebirds seldom eat small mussels on the Exe. Nor was there any evidence that disease or parasites were important. Competition from adults for food or space was not important either because spat mortality ( $\mathrm{k}_{3}$ to $\mathrm{k}_{5}$ ) was unrelated to adult density. This is in contrast to the cockle Cerastoderma edule, where adults exert a strong negative influence on settlement and survival of spat (Hancock 1973). It seems likely, therefore, that crabs were the major killers of mussel spat in the Exe estuary.

Spat seem only able to protect themselves by settling deep within the byssal threads of the already established adults. In fact on the Exe, there was a strong positive correlation $(\mathrm{r}=0.750, \mathrm{p}<0.05)$ between the densities of settled spat in March and adult densities on the beds. Frequent examination of potential settlement sites around the estuary showed that plantigrades and spat rarely occurred elsewhere than in the byssal threads of adults. Thus in contrast to cockles, spat survival benefitted from the presence of adults, at least until the beginning of their first winter. After that, many had grown too large to be protected by the byssus and were once more exposed to predation. This was the period when the strong density-dependent mortality operated.

Another interesting consequence of adults providing protected space for spat is that the failure of larvae to settle on the beds $\left(k_{3}\right)$ was inversely density dependent. High densities of adults produced both large numbers of spat and large amounts of protective byssal space, so that over 6 of 7 yr, large adult numbers allowed large numbers of spat to be recruited to the beds. The exception was 1977 when the spring spat settlement failed, clearly because most of the byssus was buried by liquid mud. By producing negative density dependence in the pre-settlement phase and positive density dependence in the post-settlement phase, crabs may thus have had 
2 directly opposing effects on the dynamics of their mussel prey.

The density-dependent check during the first winter on the beds was so powerful that the numbers of animals surviving to $1 \mathrm{yr}$ old varied within only very narrow limits between years. The regression coefficient of first winter mortality, $\mathrm{k}_{5}$, on $\log \mathrm{N}_{5}$ was 0.685 , so that above the 'critical density' (Hassell 1975) of $57 \mathrm{~m}^{-2}$, few extra individuals survived as the population density increased (Fig. 9). Though several periods of density dependence subsequently occurred during the mussel's life, these seldom contributed much to the dynamics of the population because such a strong regulatory factor had already acted upon it. That is, the critical densities above which the later mortality rates increased were seldom reached.

Any annual variation in adult numbers that did occur resulted from (1) small density-independent mortalities probably linked to the weather, (2) storm-driven immigration, probably from the sub-littoral and (3) the incompletely damped 'follow-through' to the adult population of some larger than normal spat recruitments. The last point means simply that, despite being the most powerful regulatory factor, the first-winter mortality was not perfectly compensating.

Up to 4 yr old, small winter losses were matched by small summer gains. But after the 5 th year, there were increasing post-breeding losses in summer (Worrall \& Widdows 1984) and losses from predation by oystercatchers Haematopus ostralegus in winter. Each year, these birds ate some $25 \%$ of the most productive size-

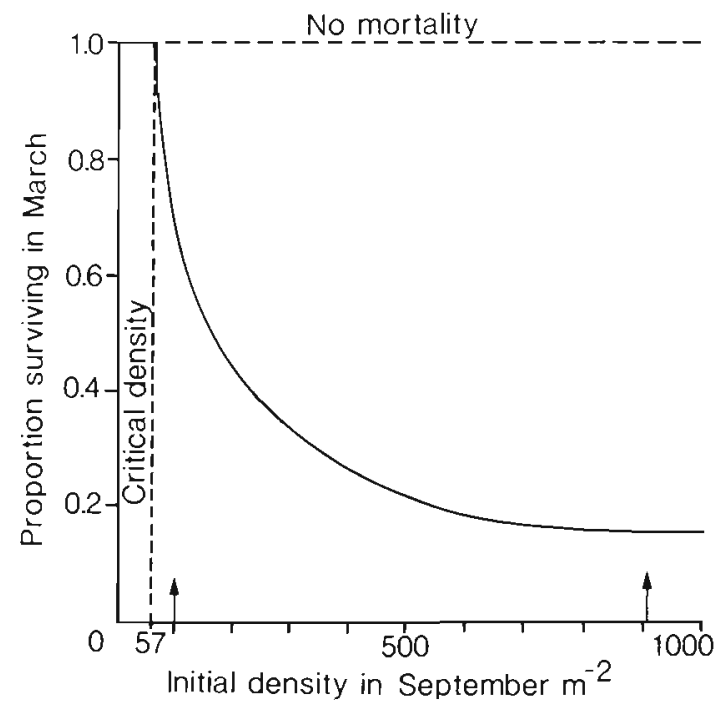

Fig. 9. Mytilus edulis. Effect of first winter density-dependent mortality, $\mathrm{k}_{5}$, on the proportion of spat surviving in March as the initial density in September $\left(\mathrm{N}_{5}\right)$ increased. Curve calculated the using equation $\mathrm{k}_{5}=0.685 \log \mathrm{N}_{5}-1.204$. Arrows: range of densities recorded classes of mussels between 30 and $60 \mathrm{~mm}$ long (Durell \& Goss-Custard 1984, Goss-Custard \& Durell 1984), just before they began spawning. Oystercatchers thus had 2 negative effects on mussel dynamics. First they reduced the number of eggs released into the plankton and, second, they removed the byssal settlement space for plantigrades and the protected space for spat. Of the 2 effects, the removal of settlement space is likely to have been the more important since so few of the eggs actually reached this stage anyway. Oystercatchers also eat cockles in their second winter, when there are large density-dependent losses (Horwood \& GossCustard 1977). As in mussels the loss of adults results in the production of fewer eggs. But unlike mussels, in which spat recruitment to established beds declines as adult density falls, in cockles more spat are recruited. Thus, predation by oystercatchers on the 2 species causes opposite results.

Mytilus edulis has a strategy common among marine benthic invertebrates of producing very large numbers of small eggs and planktonic larvae, of which only a very small proportion survive to settle and establish themselves on the seabed. However, there are differences between species in the details of population dynamics. The inverse relationship between total stock and spat in cockles, attributed to cannibalism and competition with adults (Hancock 1973, Dempster 1975) is avoided by another intertidal lamellibranch, Macoma balthica, and by $M$. edulis by spat settling initially away from the adult beds, and only at a later stage migrating onto them (Bayne 1964, Beukema 1982). Subsequently, there was a density-dependent loss of spat in both $M$. balthica in the Wadden Sea and in $M$. edulis in the Exe, but the timing was different. In $M$. balthica (Beukema 1982) the major density-dependent losses occur in summer on the nursery areas, after which they migrate in winter onto the adult beds. In $M$. edulis, on the Exe, the secondary settlement of spat occurs earlier during spring and summer, and the major losses occur afterwards on the adult beds in winter. Thus, though the overall strategy is similar, differences occur in the population dynamics during the critical first year when there are large losses.

Acknowledgements. We thank Dr J. P. Dempster and Dr M. G. Morris for constructive critisism of the manuscript. We also thank all the students who helped to collect, sort and measure seemingly endless bags of mussels.

\section{LITERATURE CITED}

Ambrose, W. G. (1986). Experimental analysis of densitydependent emigration of the amphipod Rhepoxynius abronius. Mar. Behav. Physiol. 12: 209-216

Barnett, P. R. O., Watson, J. (1986). Long-term changes in 
some benthic species in the Firth of Clyde, with particular reference to Tellina tenuis da Costa. Proc. Soc. Edinb. 90B: $287-302$

Bartlett, M. S. (1949). Fitting a straight line when both variables are subject to error. Biometrics 5: 207-212

Bayne, B. L. (1964)., Primary and secondary settlement in Mytilus edulis L. (Mollusca). J. Anim. Ecol. 33: 513-523

Bayne, B. L. (1976). The biology of mussel larvae. In: Bayne, B. L. (ed.) Marine mussels. Cambridge University Press, Cambridge, p. 81-120

Bayne, B. L., Salkeld, P. N., Worrall, C. M. (1983). Reproductive effort and value in different populations of the marine mussel, Mytilus edulis L. Oecologia 59: 18-26

Beukema, J. J. (1982). Annual variation in reproductive success and biomass of the major macrozoobenthic species living in a tidal flat area of the Wadden Sea. Neth. J. Sea Res. 16: $37-45$

Beukema, J. J., Essink, K. (1986). Common patterns in the fluctuations of macrozoobenthic species living at different places on the tidal flats in the Wadden Sea. Hydrobiologia 142: 199-207

Bhattacharya, C. G. (1967). A simple method of resolution of a distribution into Gaussian components. Biometrics 23 (1): $115-135$

Board, P. (1983). The settlement of post larval mussels (Mytilus edulis). J. mollusc. Stud. 49 (1): 53-60

Bowman, R. S. (1985). The biology of the limpet Patella vulgata L. in the British Isles: spawning time as a factor determining recruitment success. In Moore, P. G., Seed, R. (eds.) The ecology of rocky coasts: essays presented to J. R. Lewis, D, Sc. Hodder \& Stoughton, London, p. 178-193

Clarke, R. T (1982). Sub-sampling scheme for ageing size grouped mussels. Natural Environmental Research Council, Inst. Terr. Ecol. Ann. Rep. 120-121

Crowley, P. H., Nisbet, R. M., Gurney, W. S. C., Lawton, J. H. (1987). Population regulation in animals with complex lifehistories: formulation and analysis of a damselfly model. Adv. ecol. Res. 17: 1-59

Dare, P. J. (1976). Settlement, growth and production of the mussel, Mytilus edulis L., in Morecambe Bay, England. Fishery Invest., Lond. (Ser 2) 28 (1): 1-25

Dare, P. J. (1982). Notes on the swarming behaviour and population density of Asterias rubens L. (Echinodermata: Asteroidea) feeding on the mussel, Mytilus edulis L. J. Cons. int. Explor. Mer, 40: 112-118

Dare, P. J., Davies, G., Edwards, D. B. (1983). Predation of juvenile Pacific oysters (Crassostrea gigas Thunberg) und mussels (Mytilus edulis) by shore crabs (Carcinus maenas (L.)). Fish. Res. Tech. Repo, MAFF Direct. Fish. Res., Lowstoft $73: 1: 15$

Dare, P. J., Edwards, D. B. (1976). Experiments on the survival, growth and yield of relaid seed mussels (Mytilus edulis L.) in the Menai Straits, North Wales. J. Cons. int. Mer, 37 (1): $16-28$

Dare, P. J., Edwards, D. B., Davies, G. (1983). Experimental collection and handling of spat mussels (Mytilus edulis L.) on ropes for intertidal culture. Fish. Res. Tech. Rep., MAFF Direct. Fish. Res., Lowstoft 74: 1-23

Davies, G., Dare, P. J., Edwards, D. B. (1980). Fenced enclosures for the protection of seed mussels (Mytilus edulis L.) from predation by shore-crabs (Carcinus maenas [L.]). Fish Res. Tech. Rep., MAFF Direct. Fish. Res., Lowstoft 56:1-14

Dempster, J. P. (1975). Animal population ecology. Academic Press, London

Dempster, J. P. (1983). The natural control of populations of butterflies and moths. Biol. Rev. 58: 461-481
Doherty, P. J. (1983). Tropical territorial damselfishes: is density limited by aggression or recruitment? Ecology 64 (1): 176-190

Durell, S. E. A., Goss-Custard, J. D. (1984). Prey selection within a size-class of mussels. Anim. Behav. 32: $1197-1203$

Frid, C. L. J., Townsend, C. R. (1989). An appraisal of the patch dynamics concept in stream and marine benthic communities whose members are highly mobile. Oikos 56 (1): $137-141$

Gee, J. M., Warwick, R. M., Davey, J. T., George, C. L. (1985). Field experiments on the role of epibenthic predation in determining prey densities in an estuarine mudflat. Estuar. coast. Shelf Sci. 21: 439-448

Goss-Custard, J. D., Durell, S. E. A. (1984). Feeding ecology, winter mortality and the population dynamics of the oystercatcher, Haematopus ostralegus on the Exe estuary. In: Evans, P. R., Goss-Custard, J. D., Hale, W. G. (eds.) Coastal waders and wildfowl in winter. Cambridge University Press, Cambridge, p. 190-208

Goss-Custard, J. D., McGrorty, S., Reading, C. J., Durell, S. E. A. (1980). Oystercatchers and mussels in the Exe estuary. In: Boalch, G. T. (ed.) Essays on the Exe estuary. Devon Ass. Spec. Vol. 2: 161-185

Hancock, D. A. (1973). The relationship between stock and recruitment in exploited invertebrates. Rapp. P.-v. Réun. Cons. perm. int. Explor. Mer 164: 113-131

Harger, J. R. E. (1972). Variation and relative 'niche' size in the sea mussel Mytilus edulis in association with $M$. californianus. Veliger 14: 275-283

Hassell, M. P. (1975). Density dependence in single-species populations. J. Anim. Ecol. 44:283-295

Hassell, M. P. (1976). Patterns of dynamical behavior in singlespecies populations. J. Anim. Ecol. 45: 471-486

Hassell, M. P., Latto, J., May, R. M. (1989). Seeing the wood for the trees: detecting density dependence from existing life-table studies. J. Anim. Ecol, 58: 883-892

Hassell, M. P., Southwood, T R. E., Reader, P. M. (1987). The dynamics of the Viburnam Whitefly (Aleurotrachelus jelinekin: a case study of population regulation. $\mathrm{J}$. anim. Ecol. 56: 283-300

Holm, E. R. (1990). Effects of density-dependent mortality on the relationship between recruitment and larval settlement. Mar. Ecol. Prog. Ser. 60: 141-146

Horwood, J. W., Goss-Custard, J. D. (1977). Predation by the oystercatcher, Haematopus ostralegus (L.), in relation to the cockle, Cerastoderma edule (L.), fishery in the Burry Inlet, South Wales, J. appl. Ecol. 14: 139-158

Hughes, R. N., Griffiths, C. L. (1988). Self-thinning in barnacles and mussels: the geometry of packing. Am. Nat. 132: $484-491$

Hughes, R. N., Dunkin, S. de B. (1984). Effect of dietry history on selection of prey, and foraging behaviour among patches of prey, by the dogwelk, Nucella lapillus (L.). J. exp. mar. Biol. Ecol. 79: 159-172

Hughes, T P. (1990). Recruitment limitation, mortality, and population regulation in open systems: a case study. Ecology $71(1): 12-20$

Jensen, K. T., Jensen, J. N. (1985). The importance of some epibenthic predators on the density of juvenile benthic macrofauna in the Danish Wadden Sea. J. exp. mar. Biol. Ecol. 89: $157-174$

Kendall, M., Stuart, A. (1979). The advanced theory of statistics, Vol. 2, 4 th edn Griffin, High Wycombe

Kitching, J. A., Sloane, J. F., Ebling, F. J. (1959). The ecology of Loch Ine. 8. Mussels and their predators. J. Anim. Ecol. 28: $331-341$ 
Levin, L. A. (1984). Life history and dispersal patterns in a dense infaunal polychaete assemblage: community structure and response to disturbance. Ecology 65 (4): 1185-1200

Lutz, R. A. (1976). Annual growth patterns in the inner shell layer of Mytilus edulis L. J. mar. biol. Ass. U. K. 56: 723-731

Manly, B. F. J. (1990). Stage-structured populations; sampling, analysis and simulation. (Ch. 7 Key factor analysis). Chapman and Hall, London

May, R. M. (1986). The Croonian Lecture, 1985. When two and two do not make four: nonlinear phenomena in ecology. Proc. R. Soc. Lond. (B) 228: 241-266

McGrath, D., King, P. A., Gosling, E. M. (1988). Evidence for the direct settlement of Mytilus edulis larvae on adult mussel beds. Mar. Ecol. Prog. Ser. 47: 103-106

Menge, B. A., Farrell, T. M. (1989). Community structure and intraction webs in shallow marine hard-bottom communities: tests of an environmental stress model. Adv. ecol. Res. 19: 189-262

Morrisey, D. J. (1987). Effect of population density and presence of a potential competitor on the growth rate of the mud snail Hydrobia ulvae (Pennant). J. exp. mar. Biol. Ecol. 108: 275-295

Okamura, B. (1986). Group living and the effects of spatial position in aggregations of Mytius edulis. Oecologia 69: $341-347$

O'Neill, S. M., Sutterlin, A. M., Aggett, D. (1983). The effects of size-selective feeding by starfish (Asterias vulgaris) on the production of mussels (Mytilus edulis) cultured on nets. Aquaculture 35: 211-220

Paine, R. T. (1984). Ecological determinism in the competition for space. Ecology 65 (5): 1339-1348

Podolor, H., Rogers, D. (1975). A new method for the identification of key factors from life-table data. J. Anim. Ecol. 44: $85-114$

Reise, K. (1985). Tidal Flat Ecology. An experimental approach to species interactions. Springer-Verlag, Berlin

Reynolds, N. (1969). The settlement and survival of young mussels in the Conway fishery. Fishery Invest., Lond. (Ser. 2) 26: $1-24$

Roughgarden, J., Iwasa, Y (1986). Dynamics of a metapopulation with space limited subpopulations. Theor. Popul. Biol. 29: $235-261$

This article was submitted to the editor
Seed, R. (1976). Ecology. In: Bayne, B. L. (ed.) Marine mussels. Cambridge University Press, Cambridge, p. 13-66

Sheppard, R. A. (1984). Growth patterns in shells: methods of preparation and examination of transverse sections. N. Z. Jl Sci. 27: 117-122

Sigurdsson, J. B. (1976). The dispersal of young post larval bivalve molluscs by byssus threads. Nature, Lond. 262: $386-387$

Slade, N. A. (1977). Statistical detection of density dependence from a series of sequential censuses. Ecology 58: $1094-1102$

Smith, R. H. (1973). The analysis of intra-generation change in animal populations. J. Anim. Ecol, 42: 611-622

Sousa, W. P. (1985). Disturbance and patch dynamics on rocky intertidal shores. In: Pickett, S. T. A., White, P. S. (eds.) The ecology of natural disturbance and patch dynamics. Academic Press, London, p. 101-124

Stiling, P. (1988). Density-dependent processes and key factors in insect populations. J. Anim. Ecol. 57: 581-593

Thiesen, B. F. (1968). Growth and mortality of culture mussels in the Danish Waddensea. Medr Kommn Danm. Fisk -og Havunders. (N. S.) 6: 47-78

Vahl, O. (1982). Long-term variations in recruitment of the Iceland scallop, Chlamys islandica from northern Norway. Neth. J. Sea. Res. 16: 80-87

Varley, G. C., Gradwell, G. R. (1960). Key factors in population studies. J. Anim. Ecol. 29: 399-401

Varley, G. C., Gradwell, G. R. (1968). Population models for the Winter Moth. In: Southwood, T. R. E. (ed.) Insect abundance. Blackwell Scientific Publications, Oxfod, p. $132-142$

Verhagen, J. H. G. (1982). A distribution and population model of the mussel Mytilus edulis in Lake Grevelingen. Paper presented at the Third International Conference on State-of-the-Art in Ecological Modelling, Colorado State University

Walne, P. R., Dean, G. J. (1972). Experiments on predation by the shore crab, Carcinus maenas L., on Mytilus and Mercenaria. J. Cons. int. Explor. Mer 34 (2): 190-199

Worrall, C. M., Widdows, J. (1984). Investigation of factors influencing mortality in Mytilus edulis L. Mar. Biol. Lett. 5: $85-97$

Manuscript first received: March 12, 1990

Revised version accepted: July 19, 1990 